\title{
Analysis of Protein and Calcium Content in White Swallow's Nest Stew (Collacalia Fuchiphaga)
}

\section{Analisis Kandungan Protein dan Calsium Pada Rebusan Sarang Burung Walet Putih (Collacalia Fuchiphaga)}

\author{
Rio Arisandi Pratama ${ }^{1}$, Lilla Puji Lestari ${ }^{2}$ \\ ${ }^{1,2}$ Program Studi Teknik Laboratorium Medik, Universitas Maarif Hasyim Latif Sidoarjo \\ [rioarisandi@gmail.com¹, lilla_puji_lestari@dosen.umaha.ac.id²]
}

\begin{abstract}
Swallow's nest (Collocalia fuchiphaga) is one of the high export commodities. This is because the bird's nest is considered to be nutritious in terms of health. In this research, using swallow's nest obtained from several swallow buildings in Subur Indah Village, Katingan District, Kuala Central Kalimantan. The purpose of this study was to analyse the protein and calcium content of boiled white bird's nest (Collacalia Fuchiphaga). Determination of protein content was carried out using the Kjeldahl method while for determination of calcium content using the permanganometric titration method. Based on the results with 3 repetitions each, the protein content was 21.8; 22.92 and $22.15 \%$ at 4 hours of boiling then 19.7; 18.1 and 19.05\% at 8 hours of boiling. Meanwhile, the determination of the calcium content resulted in 201.5; 198.2 and $205.6 \mathrm{mg} / 100 \mathrm{~g}$ calcium at 4 hours of boiling and 182.5; 178.8 and $175.6 \mathrm{mg} / 100 \mathrm{~g}$ calcium. The conclusion in this study is that the longer it takes to boil a swallow's nest, the less protein and calcium content is obtained
\end{abstract}

Keywords : Swallow's Nest, Protein, Calcium And Boiling Time, Metode Kjeldahl, Metode Titrasi Permanganometri

\begin{abstract}
Abstrak. Sarang burung walet (Collocalia fuchiphaga) merupakan salah satu komoditas ekspor yang tinggi. Hal ini dikarenakan sarang burung walet dianggap berkhasiat dari segi keshatan. Pada penelitian kali ini menggunakan sarang burung walet yang didapat dari beberapa gedung walet di Desa Subur Indah Kecamatan Katingan Kuala Kalimantan Tengah. Tujuan daripada penelitian ini adalah untuk menganalisis kandungan protein dan kalsium pada rebusansarang burung walet putih ( Collacalia Fuchiphaga). Penetapan kandungan protein dilakukan dengan menggunakan metode kjeldahl sedangkan untuk penetapan kandungan kalsium menggunakan metode titrasi permanganometri. Berdasarkan hasil dengan masing-masing 3 kali pengulangan didapat kandungan protein sebesar 21,8; 22,92 dan 22,15 \% pada 4 jam perebusan kemudian 19,7; 18,1 dan 19,05\% pada 8 jam perebusan.sedangkan pada penetapan kandungan kalsium didapat hasil 201,5; 198,2 dan 205,6 mg/100 gr kalsium pada 4 jam perebusan serta 182,5; 178,8 dan 175,6 mg/l00 gr kalsium. Kesimpulan pada penelitian ini adalah semakin lama waktu yang digunakan untuk merebus sarang burung walet maka semakin kecil pula kandungan protein dan kalsium yang didapatkan.
\end{abstract}

Keywords : Sarang Burung Walet, Protein, Kalsium Dan Lama Waktu Perebusan.

\section{Pendauluan}

Sarang burung walet merupakan sarang burung yang terbuat dari air liur burung walet (Aerodramus sp ). Dari 24 spesies burung walet hanya 4 spesies yang dapat membentuk sarang dengan air liur dan dapat dimakan [1]. Sarang burung walwt banyak mengandung nutrisi yang baik seperti glikoprotein, dengan asam amino, karbohidrat, calcium, natrium,dan kalium [2]. Glikoprotein adalah komponen utama dalam fraksi tak larut dari sarang burung walet yang hampir $60 \%$ dari berat totalnya. Manfaat kesehatan ini burung walet berperan dalam mengatasi malnutrisi, meningkatkan sistem imun dan metabolism tubuh [3]. Efek kesehatan yang menguntungkan apabila mengkonsumsi sarang burung walet sebagai antivirus, anti-oxidant, anti-diabetes, anti-penuaan, neuro-protective dan chondroprotective [4].

Burung walet adalah insektivora dimana serangga merupakan makanannya. Burung walet secara alamiah bermigrasi dari Samudera Hindia melaui Asia Tenggara dan Australia utara hingga menuju Samudra pasifik dan bertempat tinggal di dalam gua gua kapur yang letaknya berdekatan dengan laut sehingga memeliki temperatur yang cukup dingin. Sarang burung walet yang memiliki nilai ekonomi yang cukup tinggi hanya ada pada empat spesies, 
jenis burung walet ini memiliki habitat di asia tenggara. Yang biasa dikonsumsi manusia adalah sarang dari jenis burung walet Collocalia fuchiphaga, Collocalia germanis, Collocalia maxima dan Collocalia unicolor. Sementara Sarang burung wallet yang memiliki nilai ekonomis yang tinggi berasal dari jenis burung Collocalia fuchiphaga (sarang putih) dan Collocalia maxima (sarang hitam). Setelah tahun 1880 burung walet berhasil ditangkarkan dan dibudidyakan. Dengan dibangunnya gedung yang telah dibentuk khusus untuk menjaga kelembaban inilah, ditambah dengan speaker berbunyi suara burung walet yang digunakan untuk menarik perhatin burung walet agar mau menetap dan membuat sarang digedung tersebut. Setelah menetap, burung walet tersebut keluar pada pagi hari untuk mencari makanan dan kembali saat petang.

Selain dimanfaatkan sebagai obat, sarang burung walet juga merupakan makanan yang lezat. Pengolahan sarang burung walet dengan cara direbus dan penambahan gula batu berfungsi untuk menambah citarasa dari sarang burung walet. Cara tersebut biasa digunakan untuk mengolah sarang burung walet untuk dikonsumsi secara tradisional. Negara China mengkonsumsi hampir 60\% pasar Sarang Burung Walet dunia [5]. Sarang burung walet berasal dari air liur burung walet yang mengeras. Diantara beberapa spesies yang mampu menghasilkan sarang dari air liur tersebar di Asia Tenggara, di antaranya Indonesia, Malaysia, Vietnam serta Thailand [6]. Maka dari itu, sarang burung walet merupakan salah satu komoditi utama di daerah hilir sungai katingan provinsi Kalimantan Tengah. Pada umumnya masyarakat setempat membudidayakan sarang burung walet agar dapat dijual. Namun sebagian besar masyarakat setempat hanya melihat dari segi finansial saja, tanpa mengetahui apa saja yang terkandung di dalam sarang walet tersebut dan mengapa sarang burung walet tersebut dipatok dengan harga yang sangat tinggi. Tetapi terlalu banyak rumor yang beredar di internet tentang khasiat dan bagaimana cara penyajian sarang burung walet ini. Seperti dilansir pada borneonews.co.id, dalam setahun hasil budidaya sarang walet mencapai 50 ton. Namun jumlah tersebut hanya sebagian saja karena para pengepul juga banyak yang langsung membawa keluar daerah.

Pada penelitian sebelumnya dengan judul (Analisis Profil Protein Dan Asam Amino Sarang Burung Walet (Collocalia Fuchiphaga) Asal Painan) menggunakan metode semi mikro kjedahl memperoleh hasil dari kadar protein sebesar 55,62\% [7]. Sedangkan pada penelitian penentuan kadar kalsium dengan metode permanganometri terhadap tempe yang dibungkus plastic dan daun di pasar Arengka Pekanbarui didapatkan rata-rata kandungan kalsium sebesar $0,704 \%$ [8]. Dari sekian banyak khasiat yang terdapat pada sarang walet, penulis memilih analisis protein karena untuk mengetahui adakah perbedaan hasil penelitian yang dilakukan oleh penulis dengan hasil penelitian yang dilakukan oleh penulis lain, dan alasan penulis melakukan penelitian untuk mengetahui besaran kandungan kalisum karena penulis belum menemukan adanya analisa kalsium pada sarang walet pada literatur lain.

\section{METODE}

Penelitian dilaksanakan pada tanggal 1 April 2020 yang berlokasi di Laboratorium Balai Penelitian dan Konsultasi Industri. Dalam penelitian kali ini alat -alat yang dibutuhkan antara lain neraca analitik, labu kejldahl, bunsen, labu didih, alat penyling, erlenmeyer, tabung buret, kertas saring dan gelas piala. Bahan yang digunakan sebagai sampel adalah sarang burung walet (Collocalia fuchipaga) yang secara acak diambil di Desa Subur Indah, Kab. Katingan Kalimantan Tengah. Sampel diambil dari gedung khusus yang dimanfaatkan untuk mengembangbiakkan sarang burung walet tersebut. Sampel dibersihkan terlebih dahulu sebelum dilakukan pengiriman untuk menghindari terjadinya kontaminasi. Sedangkan bahan kimia yang dipakai adalah Celen, H2SO4 pekat, aquades, $\mathrm{NaOH} 30 \%, \mathrm{NaOH}, \mathrm{HCl} 0,5 \mathrm{~N}$, Ammonium oksalat, $\mathrm{H} 2 \mathrm{SO} 425 \%$ dan $\mathrm{KMnO} 40,1 \mathrm{~N}$.

Untuk perlakuan yang pertama sampel berupa sarang burug walet terebih dahulu direndam didalam air mendidih selama 4 dan 8 jam, kemudian dilakukan penetapan kandungan protein dan kalsium yang dilakukan 3 kali pengulangan. Setelah itu dilakukan penetapan kandungan protein dengan cara memasukkan 1-2 gr sampel kedalam labu kjeldahl kemudian ditambahkan $10 \mathrm{gr}$ selen, dan $30 \mathrm{ml}$ asam sulfat pekat. Kemudian dipanaskan pada api kecil sambil digoyang-goyang selama 5-10 menit, lalu api dibesarkan sampai warna larutan berubah menjadi hijau. Dinginkan beberapa saat, setelah itu encerkan dengan $250 \mathrm{ml}$ aquades kemudian dipindahkan ke dalam labu didih yang sebelumnya telah ditambahkan beberapa butir batu didih. Lalu ditambah $120 \mathrm{ml} \mathrm{NaOH} 30 \%$ dan segera disambung dengan alat penyuling dan disuling sampai $2 / 3$ dari larutan tersebut tersuling. Sulingan yang terdapat ditampung dalam $\mathrm{HCl}$ 0,5 N kelebihan. Akhirnya kelebihan $\mathrm{HCl}$ tersebut dititrasi kembali dengan $\mathrm{NaOH}$ dengan titik akhir titrasi berupa biru kehijau-hijauan. Setelah itu dilihat berapa banyak $\mathrm{NaOH}$ yang digunakan untuk mencapai titik akhir titrasi dan dimasukkan ke dalam perhitungan untuk menentukan seberapa besar kandungan protein sebagai berikut 
$\%$ protein $=\frac{(\text { blangko }-\mathrm{ml} \mathrm{NaOH}) \times \mathrm{N} . \mathrm{NaOH} \times 0,014 \times 6,37}{\text { gr. sampel }} \times 100 \%$

\section{A. Penetapan Kandungan Kalsium}

Merendam sampel dengan Ammonium oksalat didalam gelas piala hingga menghasilkan endapan dalam satu malam, lalu cuci dengan air panas. Endapan dan kertas saring dimasukkan kembali kedalam piala bekas mengendapan kemudian ditambah $\pm 10 \mathrm{ml} \mathrm{H} 2 \mathrm{SO} 425 \%$ sampai endapan larut. Panaskan $70^{\circ} \mathrm{C}$, titrasi dengan KMnO4 0,1 N. Setelah itu dilihat berapa banyak H2SO4 yang dipakai dalam mencapai titik akhir titrasi, setelah itu dimasukkan ke dalam perhitungan untuk menentukan seberapa besar kandungan kalsium sebagai berikut

$$
\% \text { PROTEIN }=\frac{(\mathrm{ml} \mathrm{KMnO4-blanko)} \times \mathrm{N} . \mathrm{KMnO4} \times 0,02}{\text { gr. sampel }} \times 100 \%
$$

\section{Hasil Dan PeMbahasan}

Sarang burung walet terdiri dari karbohidrat, protein dan air liur, Dalam penelitian ini kami juga mendukung fakta bahwa fraksi tak larut air sarang burung walet kaya akan protein, karbohidrat dan asam sialic. Protein sebagai jenis makromolekul biologis dianggap sebagai komponen nutrisi utama yang penting dan mempengaruhi tekstur dan sifat fungsional makanan [9]. Sedangkan kelarutan meupakan karakteristik penting dari protein yang sangat mempengaruhi sifat fungsional protein seperti pembusaan, pembentuk gel dan pengelmulsi [10].

Sampel sarang burung walet yang digunakan dalam penelitian ini diperoleh dari berbagai gedung walet yang tersebar di desa Subur Indah, kecamatan katingan kuala, kalimantan tengah. Penetapan kandungan protein sarang burung walet dilakukan dengan menggunakan metode kjeldahl dimana penggunaan campuran selen sebagai katalisator dalam mempercepat reaksi destruksi dan penambahan selen berfungsi sebagai perusak senyawa organik membentuk protein menjadi ammonium sulfat. Dengan penambahan $\mathrm{NaOH}$ mengubah ammonium sulfat dalam proses destilasi menjadi amoniak yang ditampung dengan $\mathrm{HCl}$ menjadi ammonium klorida. Sisa klorida di titrasi dengan $\mathrm{NaOH}$. Pada penetapan kandungan kalsium dilakukan dengan menggunakan titrasi permanganometri dimana sampel yang diendapkan bersama amonium oksalat lalu ditambahkan H2SO4 untuk melarutkan Calsium Oksalat menjadi Calsium Sulfat. Lalu dilakukan titrasi dengan KMnO4. Hasil yang diperoleh dalam penelitian ini ditampilkan dalam tabel berikut.

Tabel 1. Hasil penetapan kandungan protein

\begin{tabular}{|c|c|c|c|c|c|c|}
\hline \multicolumn{4}{|c|}{4 jam } & \multicolumn{3}{|l|}{8 jam } \\
\hline $\begin{array}{l}\text { Titrasi } \\
\mathrm{NaOH}\end{array}$ & 0,94 & 0,84 & 0,63 & 2,83 & 4,26 & 3,41 \\
\hline$\%$ protein & 21,80 & 21,92 & 22,15 & 19,70 & 18,10 & 19,05 \\
\hline
\end{tabular}

Tabel 2. Hasil penetapan kandungan kalsium

\begin{tabular}{lccc|ccc}
\multicolumn{3}{c}{ 4 jam } & & & $\mathbf{8}$ jam & \\
Titrasi & & & & & & \\
KMnO4 & 0,88 & 0,86 & 0,89 & 0,79 & 0,78 & 0,76 \\
\hline $\begin{array}{l}\text { mg/100g } \\
\text { kalsium }\end{array}$ & 201,5 & 198,2 & 205,6 & 182,5 & 178,8 & 175,6 \\
\hline
\end{tabular}

\section{KESIMPULAN}

Dalam uji penetapan kadar protein menggunakan metode kjeldahl didapat hasil rata-rata prosentase sebesar 21,96 \% pada 4 jam perebusan dan 18,95\% pada 8 perebusan, sedangkan penetapan kadar kalsium didapat rata-rata hasil sebesar 201,8 mg/100 gr kalsium pada 4 jam perebusan dan 179 mg/100 gr kalsium pada 8 jam perebusan. 


\section{REFERENSI}

[1] L. C. Koon. Feature-Bird's Nest soup-market demand for this expensive gastronomic delicacy threatens the aptly name edible-nest Swiftlet with extinction in the east. Wildlife Conservation.103. (2000).(1): 30-35.

[2] M. K. Norhayati, O. Azman \&W. M. Wan Nazaimoon. Preliminary study of the nutritional content of malaysian edible bird's nest. Malaysian Journal of Nutrition. (2010).16 (3): 389-396.

[3] Z. Hamzah, N.H. Ibrahim, Sarojini, K. Hussin, O. Hashim, and B.B.Lee. Nutritional properties of edible bird nest. J. As. Sci.Res. 3(6):600-607, 2013.

[4] Soi Moi, C., Tai, S., Koh, R. Y., \& Ng, K. (2017). A mini review on medicinal effects of edible bird's nest. Letters in Health and Biological Sciences, 2, 1-3. https://doi.org/ 10.15436/2475-6245.17.016.

[5] W. Andayani, E. Prihartini, M. Sariningsih. Deteksi kadar nitrat dan nitrit pada komoditas sarang burung walet yang diekspor melalui bandara internasional juanda. Laboratorium Uji Karantina Hewan Balai Besar Karantina Pertanian Surabaya, 2012.

[6] L. Guo, Y. Wu, M. Liu, B. Wang, Y. Ge, Y. Chen. Authentication of Edible Bird"s Nests By TaqMan-based Real-Time PCR. Food Control (44): 220-226, 2014.

[7] L. Elfita. (2014). Analisis Profil Protein dan Asam Amino Sarang Burung Walet (Collocalia fuchipaga) Asal Painan. Jurnal Sains Farmasi \& Klinis, 1(1) 27-37.

[8] S. Rahmadani. (2011). Penentuan kadar kalsium dengan metode permanganometri terhadap tempe yang dibungkus plastik dan daun di pasar Arengka Pekanbaru (Doctoral dissertation, Universitas Islam Negeri Sultan Syarif Kasim Riau).

[9] Kinsella, E. John, and Nicholas Melachouris. "Functional properties of proteins in foods: a survey." Critical Reviews in Food Science \& Nutrition 7.3 (1976): 219-280.

[10] Ling, Bo, Shaohui Ouyang, and Shaojin Wang. "Radio-frequency treatment for stabilization of wheat germ: Storage stability and physicochemical properties." Innovative Food Science \& Emerging Technologies 52 (2019): 158-165. 